\title{
Comfort's evolution analysis of low-cost housing in Ciudad Valles, S.L.P.
}

\section{Análisis de la evolución del confort en la vivienda en serie en Ciudad Valles, S.L.P.}

ZAPATA-PADILLA, Néstor Juan†*, GÓMEZ-PEDRAZA, Carlos, BOJÓRQUEZ-VARGAS, Alma Rafaela and HERNÁNDEZ-GONZÁLEZ, Beatriz Gisela

Facultad de Estudios Profesionales Zona Huasteca de la Universidad Autónoma de San Luis Potosí

ID $1^{\text {st }}$ Author: Néstor Juan, Zapata-Padilla / ORC ID: 0000-0003-3367-3589, CVU CONACYT ID: 898332

ID $1^{\text {st }}$ Co-author: Carlos, Pedraza-Gómez / ORC ID: 0000-0003-2308-2857, CVU CONACYT ID: 334939

ID $2^{\text {nd }}$ Co-author: Alma Rafaela, Bojórquez-Vargas / ORC ID: 0000-0001-9959-5320, CVU CONACYT ID: 162577

ID 3er Co-author: Beatriz Gisela, Hernández-González / ORC ID: 0000-0002-7473-9583, CVU CONACYT ID: 816192

DOI: $10.35429 / J A D .2021 .13 .5 .13 .28$

Received March 23, 2021; Accepted June 17, 2021

\begin{abstract}
This research is the product of the monitoring carried out from year 2019 to 2020 about the environmental parameters that determine the person's comfort in six low-cost housing in Ciudad Valles, San Luis Potosí, México. These buildings were built in 1985, 1987, 1990, 1997, 2006 and 2008 respectively, between 1972 to 2006, foundation of INFONAVIT and CONAVI respectively, period of interest to analyze the thermal behavior of materials as block and concrete, which transcend the time due to their industrialization characteristics rather than their benefits in the person's termal confort. The main objective is analyzes and demonstrate the thermal confort evolution provided by these classic materials in the hygrothermal environment, in order to suggest adjustments to improve it. the research questions are next; Do the classic materials provide a comfortable environment? How is the evolution of thermal comfort in the interior of the low-cost housing when building them with cement block and concrete? And if not; What are the recommendations to generate a better thermal environment? With the support of the PRODEP 2018 Program, some measuring equipment is obtained that are used to record the relative humidity, temperature, wind speed and temperature of the materials like the floor, the roof and the walls.
\end{abstract}

\begin{abstract}
Resumen
La presente investigación es producto del monitoreo que se realiza del año 2019 al 2020 sobre los parámetros ambientales que determinan el confort térmico de la persona en seis viviendas de interés social dentro de la zona urbana de Ciudad Valles, San Luis Potosí, México. Estos inmuebles fueron construidos en los años 1985, 1987, 1990, 1997, 2006 y 2008 respectivamente, dentro del periodo comprendido entre 1972, fundación del INFONAVIT, y 2006, fundación de CONAVI, periodo de interés para analizar el comportamiento térmico de los materiales como el block de cemento y el concreto, mismos que trascienden las épocas por sus características de industrialización más que por sus beneficios en la calidad del ambiente micro climático. El objetivo principal del estudio es analizar y evidenciar la evolución del confort térmico que brindan estos materiales clásicos en el ambiente higrotérmico, con el fin de sugerir adecuaciones para mejorarlo. Responde a las preguntas de investigación; ¿Lo materiales clásicos propician un ambiente confortable?, ¿Cuál ha sido la evolución del confort térmico en el interior de la vivienda de interés social al construirlas a base de block de cemento y concreto?, y de no hacerlo; ¿Cuáles son las recomendaciones para generar un mejor ambiente térmico? Con apoyo del Programa para el Desarrollo Profesional Docente del año 2018, se obtienen algunos equipos de medición que se utilizan para registrar la humedad relativa, la temperatura, la velocidad del viento y le temperatura de los materiales que conforman la envolvente; el piso, la cubierta y los muros.
\end{abstract}

Confort. Evolución. Vivienda de interés social 


\section{Introduction}

It is common to find environments created by man who are worse than the natural environment, this contrasts with the role of architecture and urban planning to give a man an environment according to his needs. A new architecture and good urban planning must necessarily relate man, architecture, and climate, achieving a conciliation between them. The applications of thermal comfort indicators in urban and regional planning and in urban design continue to be primary in developing countries, despite strong empirical evidence of the benefits provided by urban afforestation strategies, furniture, and urban morphology to the improvement of local and regional climatic conditions (Tornero et al, 2006). The meeting point, however, between urban design and urban climate has an approach in bioclimatic urbanism, understood as one that seeks to achieve urban areas with a thermal balance (comfort zones) according to local climatic preexistence through design, urban that allows obtaining a form and urban spaces that enhance these conditions (Higueras, 1998); This could be mentioned, according to Tornero et al 2006; p. 163 that:

While Erell, et al (2011) organize this list into two areas of study on urban microclimate's:

1. The study of the effect of urban microclimates on human activities, especially at the level of pedestrians and the space between buildings and 2 . The study of the effect of microclimate on the performance of buildings, specifically in the field of conservation of the Energy.

Regarding the first area, Erell (op. Cit.), points out that the conformation of urban fabrics and the climate created by them, influences how these spaces are used; for example, when it is desired that there is a greater pedestrian appropriation of the city, optimal external conditions of comfort must be created for this appropriation to occur. As an effect of the creation of climatically comfortable public spaces and their citizen appropriation, for example, a reduction in energy consumption can be expected by relying less on mechanical systems in homes, simply put.
By spending more time in public space Household thermal conditioning systems are used less (Erell et al, 2011; p142).

While in the second area, the effect of the urban climate on the energy consumption of buildings is widely recognized, thus, for example, it has been shown that the increase in energy demand reaches significant levels in periods of extreme temperatures, thus it is associated that energy demand to achieve comfort levels inside buildings is directly correlated with outside temperatures (Santamouris et al, 2001).

Likewise, different urban morphological configurations are directly associated with higher energy consumption in buildings, due to the poor relation of buildings with preexisting climatic conditions. For example, Souza et al (2004), correlate the urban canyon effect (warm air stagnation, SVF, building height $(\mathrm{H}) /$ street width (W) $\mathrm{H} / \mathrm{W}$ ratio, orientation) with higher energy consumption in buildings. The buildings that make them up. This reaction of the energy performance of buildings, using mechanical means to achieve comfortable conditions, contributes thermal gains to the city's energy balance, which in sum creates harmful effects on local climate comfort such as the Urban Heat Island, ICU, and degenerate the environmental quality of the city.

While the spatial scales of urbanregional planning in reference to the present climatic conditions and the atmospheric scales of the urban climate are relevant for the formulation of adequate strategies to solve the adverse effects of the urban climate (Katzchner, 2010). Thus, urban development plans and city intervention plans (administrative level scale 1: 25,000 ) can address the adverse effects of the ICU and the improvement of urban ventilation patterns (climatic mesoscale), while planning and intervention in neighborhoods should ensure thermal comfort and air pollution problems; At the municipal level, the quality of urban space (parks, urban vegetation, urban furniture) can help to reverse the negative effects of thermal discomfort, while building regulations for individual buildings can create architectural conditioning factors that allow better design based on improve the thermal balance of the city due to radiation effects on surfaces (materiality, envelopes, colors, roofs and vegetated walls, among others).

ZAPATA-PADILLA, Néstor Juan, GÓMEZ-PEDRAZA, Carlos, BOJÓRQUEZ-VARGAS, Alma Rafaela and HERNÁNDEZGONZÁLEZ, Beatriz Gisela. Comfort's evolution analysis of low-cost housing in Ciudad Valles, S.L.P.Journal of Architecture and Design. 2021 
However, these planning challenges must be approached from the scientific certainty to make decisions based on evidence that demonstrates the benefits of the interventions, regarding this empirical need, the literature (Ren et al, 2009) indicates examples of cities in countries such as Germany, which have developed urban-regional climate maps for decision-making in the planning of regions and cities based on high-precision climate studies and with the help of urban planners, maps of intervention recommendations have been prepared; Ren et al, 2009; where they present a diagram of how local climate information, especially urban climate, should be transferred to urban planning.

The bioclimatic city is not exclusively the sum of buildings that incorporate passive conditioning techniques. The new scale implies other types of interactions and problems that must be addressed from a systemic perspective. In this sense, bioclimatic criteria are very appropriate for general planning, with the aim of trying to close the ecological cycles of matter and energy, reduce the ecological footprints of settlements, minimize negative impacts on air, water, and soil. And also, to efficiently use the available energies. Ultimately, it is about advancing on the path of sustainability in our cities. (Higueras, 2013)

The micro-urban-architecturalenvironmental scale of the study allows us to analyze the thermal process that social interest housing goes through to expose the lack and need for advances, research and studies on the construction materials used in mass building., as are the subdivisions of the public or private sector, where they prioritize urban growth over bioclimatic urban development, which contributes to the quality of life and comfort of the user.

The application of the Olgyay and Givoni diagrams becomes a useful tool and must be incorporated into regional climate studies, despite the difficulties derived from the lack of information on many parameters required for their elaboration.

They make it possible to adapt bioclimatic designs to achieve hygrothermal comfort depending on the time of year and the climate according to the geographical location of the building.
The usefulness of the diagrams is indisputable; however, the problem consists, first in determining the comfort limits, which are different according to authors and zones and, secondly, using the appropriate data of temperature and humidity, which should be hourly or, at least representative of the different environments that occur throughout the day, especially in climates as contrasting as those in the interior of the Peninsula.

Surveys on the perception of heat are quite useful for research, since they work to determine if the temperature and relative humidity ranges of the diagrams are adequate for the area and for the degree of tolerance or adaptability that people acquire after being City residents and their local climate.

In this way, as shown in the graph 1, the perception that 512 users has regarded the interior environment of their home is obtained first-hand, which guides the direction of the investigation.

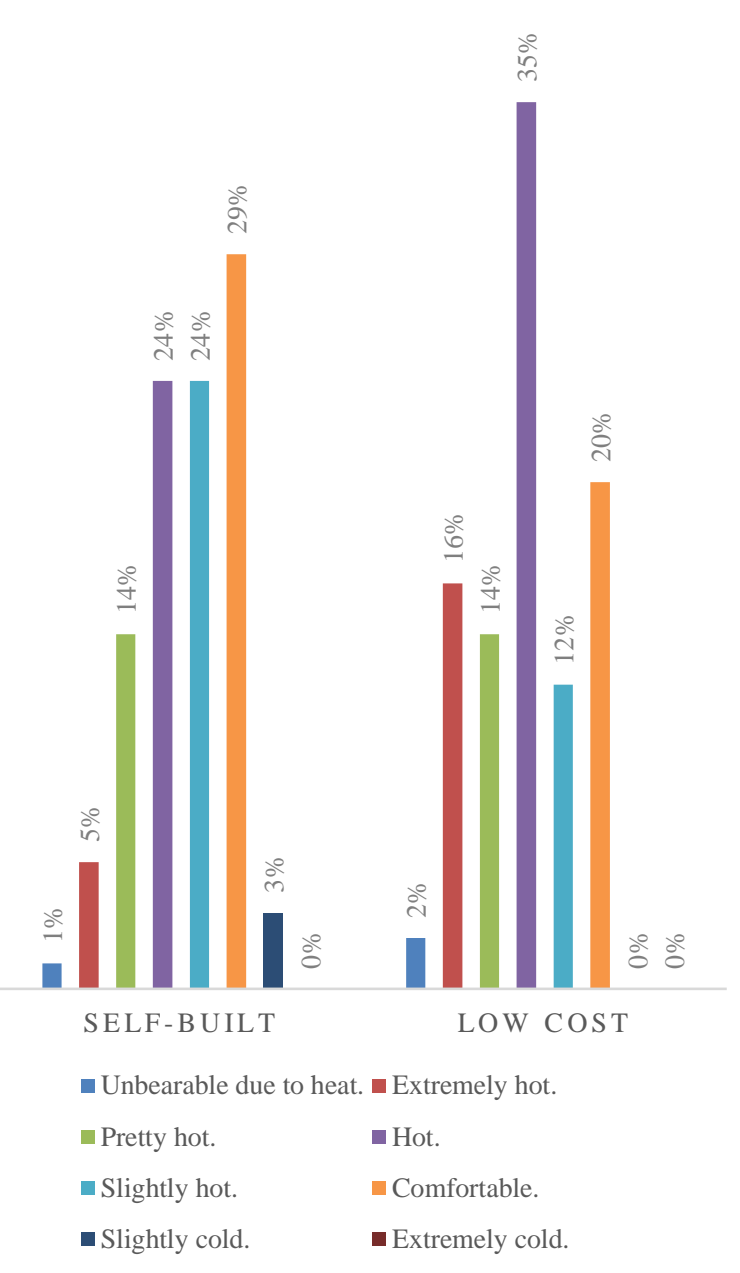

Graph 1 Inside homes environment perception Source: Own Elaboration 
Second, it is necessary to perform previous measurements of the environmental parameters at the time of conducting the survey, to relate the response of the people with the ranges of the comfort zone; in such a way that subjective data can be linked to objective data; in this case the sensation of the human body (subjective) to the environmental conditions, whose magnitude (objective hard data) is known.

The increasing amount of research dedicated to the climate of urban areas is a favorable factor for the generalized implementation of these psychometric charts, which allows evaluating an element of the environment that is of great utility for urban planning and the rational use of the spaces of man. The most important parameters for the feeling of comfort, according to the diagrams are temperature, relative humidity, and wind speed.

Temperature as such is the magnitude with which the heat transfer from the hottest to the coldest body is recorded and is recorded in degrees centigrade $\mathrm{C}^{\circ}$. The higher the heat, the higher the temperature: and as a rule; during the day, materials absorb and store heat from direct and diffuse solar radiation for the latter; over the course of the night, dissipate it.

This even causes the interior environment of some buildings to become warmer at night than on the same day; due to the radiant temperature that expels the architectural envelope toward the interior.

Relative humidity is defined as the volume of air that a cubic meter of air contains, expressed as a percentage, and is used to determine the thermal sensation of the environment. For this type of analysis, it is necessary to have this climatic variable that independently could only show the absence of the wind, while the\% of R.H. it is high, and therefore sweating can be excessive as it does not evaporate because the environment does not allow it because it is saturated, in addition to complicating the person's breathing by making the air heavier.

Otherwise, when the humidity is low, it indicates that the wind is present and the air, being unsaturated, allows evaporation by accepting more volume of water.
As a general rule, it can be reported that at elevated temperatures, the percentage of relative humidity decreases, and at low temperatures, the\% R.H. increases. In the interior environment of a house with elevated temperatures and little ventilation, the sensation of heat increases and sweating increases, therefore the space is hardly comfortable. In the case of the wind; This is caused by the differences in temperature that exist due to the uneven heating of the different areas of the Earth and the atmosphere, for particular studies, it is difficult to analyze it since it depends rather on considerable masses of warmer air that tend to rise, and its place is then occupied by the surrounding air masses, colder and, therefore, denser; therefore, the density and porosity of the surfaces in areas as small as a plot of land or the roof of a house would hardly make any changes to the natural system that generates the wind.

On the surface, the wind is defined by two parameters: the direction in the horizontal plane and the speed, for this type of study we are interested locally, since on this scale it is possible to intervene with the support of elements that are within human reach., such as the vegetation, the morphology and magnitude of constructions, however the elements to intervene are at an urban level such as the direction of the layout, the materials of large bodies such as roads and green areas such as parks, the height and shape of the obstructions such as buildings and trees, in addition to the orientation and geographical location such as altitude and topography of the site.

\subsection{Analysis of the climatic conditions of Ciudad Valles, S.L.P.}

Ciudad Valles, San Luis Potosí is located at the geographical coordinate $21^{\circ} 59^{\prime} 12^{\prime \prime} \mathrm{N} 99^{\circ}$ $01^{\prime} 07^{\prime \prime} \mathrm{W}$, located at 85 meters above sea level, has a warm subhumid AW0 climate with a considerable relative humidity of $78 \%$ due to the influence of hydrology and abundant vegetation due to its proximity to the Sierra Madre Oriental, the average temperature is 24.7 ${ }^{\circ} \mathrm{C}$; minimum of $6^{\circ} \mathrm{C}$ and maximum of $47^{\circ} \mathrm{C}$ according to information from the SMNCONAGUA; and according to city newspapers; up to $56^{\circ} \mathrm{C}$ with a temperature sensation of 60 $\circ \mathrm{C}$; the wind speed is $6 \mathrm{~km} / \mathrm{hr}$. on average coming from the northwest.(SMN and CONAGUA, 2011). 
With the help of the Confex program, table 1.0 is produced which is related to table 2 ; where the recommendations to counteract the environmental conditions of the City are described, which are valued based on the climatological normal of the National Meteorological Service, SMN, and the National Water Commission, CONAGUA.

\begin{tabular}{|l|l|l|l|l|l|l|l|l|l|l|l|l|}
\hline Hour & \multicolumn{10}{|c|}{ Months of the year. } \\
\hline 24 h & E & F & M & A & M & J & J & A & S & O & N & D \\
\hline $01: 00$ & & & & & & & & & & & & \\
\hline $02: 00$ & & & & & & & & & & & & \\
\hline $03: 00$ & & & & & & & & & & & & \\
\hline $04: 00$ & & & & & & & & & & & & \\
\hline $05: 00$ & & & & & & & & & & & & \\
\hline $06: 00$ & & & & & & & & & & & & \\
\hline $07: 00$ & & & & & & & & & & & & \\
\hline $08: 00$ & & & & & & & & & & & & \\
\hline $09: 00$ & & & & & & & & & & & & \\
\hline $10: 00$ & & & & & & & & & & & & \\
\hline $11: 00$ & & & & & & & & & & & & \\
\hline $12: 00$ & & & & & & & & & & & & \\
\hline $13: 00$ & & & & & & & & & & & & \\
\hline $14: 00$ & & & & & & & & & & & & \\
\hline $15: 00$ & & & & & & & & & & & & \\
\hline $16: 00$ & & & & & & & & & & & & \\
\hline $17: 00$ & & & & & & & & & & & & \\
\hline $18: 00$ & & & & & & & & & & & & \\
\hline $19: 00$ & & & & & & & & & & & & \\
\hline $20: 00$ & & & & & & & & & & & \\
\hline $21: 00$ & & & & & & & & & & & & \\
\hline $22: 00$ & & & & & & & & & & & & \\
\hline $23: 00$ & & & & & & & & & & & & \\
\hline $00: 00$ & & & & & & & & & & & & \\
\hline
\end{tabular}

Table 1 Evaluation of environmental conditions for Ciudad Valles

Source: Own Elaboration

\begin{tabular}{|c|c|c|c|}
\hline $\begin{array}{l}\text { Color } \\
\text { Month }\end{array}$ & & Hour & Recommendations \\
\hline $\begin{array}{l}\text { Red } \\
\text { May } \\
\text { September. }\end{array}$ & to & $\begin{array}{l}11: 00 \mathrm{~h} \text { to } \\
19: 00 \mathrm{~h}\end{array}$ & $\begin{array}{l}\text { Control of solar radiation, } \\
\text { relative humidity and radiant } \\
\text { temperature. Mechanical } \\
\text { ventilation is required. }\end{array}$ \\
\hline $\begin{array}{l}\text { Orange } \\
\text { April. }\end{array}$ & & $\begin{array}{l}13: 00 \mathrm{~h} \text { to } \\
15: 00 \mathrm{~h}\end{array}$ & $\begin{array}{l}\text { Control of solar radiation and } \\
\text { radiant temperature. Generate } \\
\text { wind. }\end{array}$ \\
\hline $\begin{array}{l}\text { Yellow } \\
\text { March } \\
\text { November. }\end{array}$ & to & 24 hours. & $\begin{array}{l}\text { Reduce the relative humidity, } \\
\text { the radiant temperature and the } \\
\text { solar radiation of the day. }\end{array}$ \\
\hline $\begin{array}{l}\text { Gray } \\
\text { December } \\
\text { January. }\end{array}$ & to & $\begin{array}{l}11: 00 \mathrm{~h} \text { to } \\
17: 00 \mathrm{~h}\end{array}$ & $\begin{array}{l}\text { It is not necessary to intervene } \\
\text { while there are solar } \\
\text { obstructions. }\end{array}$ \\
\hline $\begin{array}{l}\text { Gray } \\
\text { February. }\end{array}$ & & $\begin{array}{l}\text { 10:00h a } \\
13: 00 \mathrm{~h}\end{array}$ & $\begin{array}{l}\text { It is not necessary to intervene } \\
\text { while there are solar } \\
\text { obstructions. }\end{array}$ \\
\hline $\begin{array}{l}\text { Blue } \\
\text { November, } \\
\text { December, } \\
\text { January } \\
\text { February. }\end{array}$ & and & $\begin{array}{l}\text { Antes de las } \\
10: 00 \mathrm{~h} \quad \mathrm{y} \\
\text { despues de } \\
\text { las } 18: 00 \mathrm{~h}\end{array}$ & $\begin{array}{l}\text { Decrease the wind and increase } \\
\text { the radiant temperature. }\end{array}$ \\
\hline $\begin{array}{l}\text { Purple } \\
\text { January, } \\
\text { February } \\
\text { December. }\end{array}$ & and & $\begin{array}{l}3: 00 \mathrm{~h} \mathrm{a} \\
8: 00 \mathrm{~h}\end{array}$ & Increase radiant temperature. \\
\hline
\end{tabular}

Table 2 Bioclimatic recommendations for Ciudad Valles Source: Own Elaboration
As can be seen in table 1 and table 2, Ciudad Valles has an unfavorable climate in most of the year and hours of the day, so it is anticipated that a good thermal performance of the materials must be necessary to cushion the climatic effects in the interior of the house.

\subsection{Characteristics of the series housing studied in Ciudad Valles, S.L.P.}

The series dwelling that is identified in the urban area of the city and the dwellings for the study; it is orthogonal in shape, built on a 12 cm- wide cement block and a ferroconcrete structure composed of enclosures of a minimum width equal to that of the block and a solid hydraulic concrete cover with an average thickness of $10 \mathrm{~cm}$, regularly flat with slight slope. The construction surfaces oscillate in the $40 \mathrm{~m}^{2}, 60 \mathrm{~m}^{2}$, and $80 \mathrm{~m}^{2}$; within a plot with variable orientations that on average has an area of $90 \mathrm{~m}^{2}$.

The average height of the house is 2.50 $\mathrm{m}$ with a minimum of $2.40 \mathrm{~m}$; and they have two bedrooms, a dining room, a kitchenette, a bathroom and the hallway or service patio. The following table 3 shows the year of construction, the geographical location and the orientation of the case studies.

\begin{tabular}{|c|c|c|c|c|}
\hline Case & Year & Geographical location & Orientation & Levels \\
\hline $\mathrm{C} 1$ & 1985 & $\begin{array}{l}22^{\circ} 0^{\prime} 51.93 " \mathrm{~N} \\
99^{\circ} 00^{\prime} 20.76^{\prime \prime O}\end{array}$ & NW-SE & 1 \\
\hline $\mathrm{C} 2$ & 1987 & $\begin{array}{l}21^{\circ} 57^{\prime} 33.41 " \mathrm{~N} \\
98^{\circ} 59^{\prime} 29.19^{\prime \prime} \mathrm{O}\end{array}$ & NE-SW & 1 \\
\hline C3 & 1990 & $\begin{array}{l}21^{\circ} 59^{\prime} 45.55^{\prime \prime} \mathrm{N} \\
98^{\circ} 59^{\prime} 25.89^{\prime \prime} \mathrm{O}\end{array}$ & NE-SW & 1 \\
\hline $\mathrm{C} 4$ & 1997 & $\begin{array}{l}22^{\circ} 1 ' 43.53^{\prime \prime} \mathrm{N} \\
99^{\circ} 1 ' 29.85^{\prime \prime} \mathrm{O}\end{array}$ & $\mathrm{N}-\mathrm{S}$ & 1 \\
\hline $\mathrm{C} 5$ & 2006 & $\begin{array}{l}22^{\circ} 0 ' 37.07 " \mathrm{~N} \\
98^{\circ} 59^{\prime} 51.95 " \mathrm{O}\end{array}$ & NE-SW & 2 \\
\hline C6 & 2008 & $\begin{array}{l}22^{\circ} 1 ' 31.61 " \mathrm{~N} \\
99^{\circ} 1 ' 19.22^{\prime \prime} \mathrm{O}\end{array}$ & $\mathrm{N}-\mathrm{S}$ & 1 \\
\hline
\end{tabular}

Table 3 Geographical location of the case studies Source: Own Elaboration

The following table shows the house's spaces. 


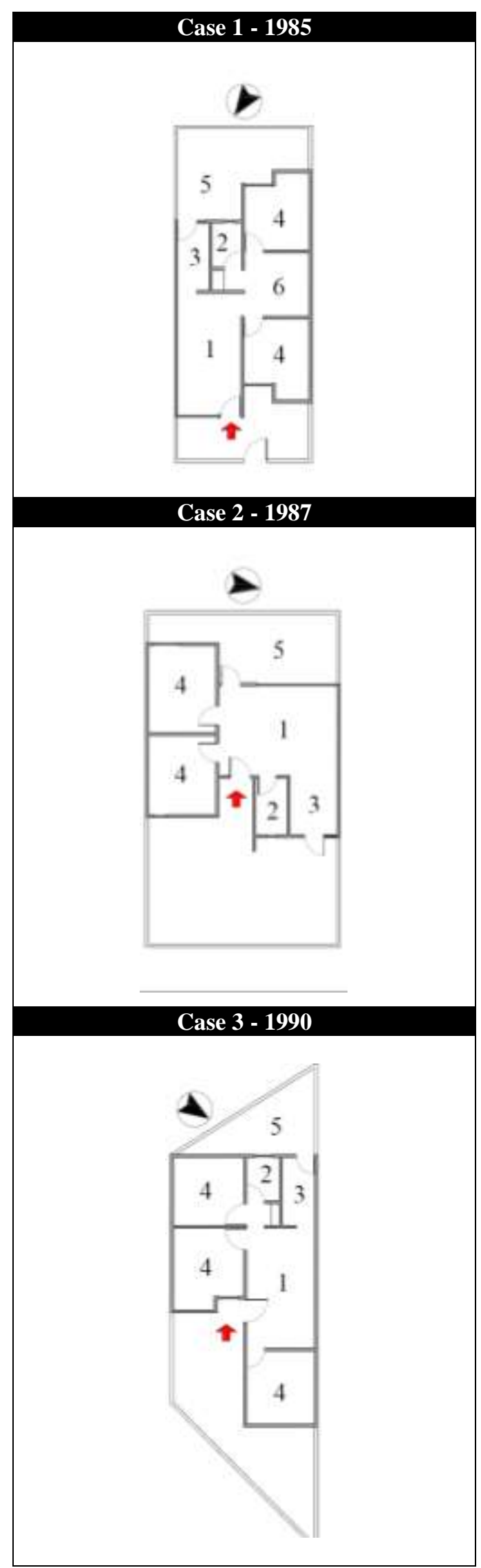

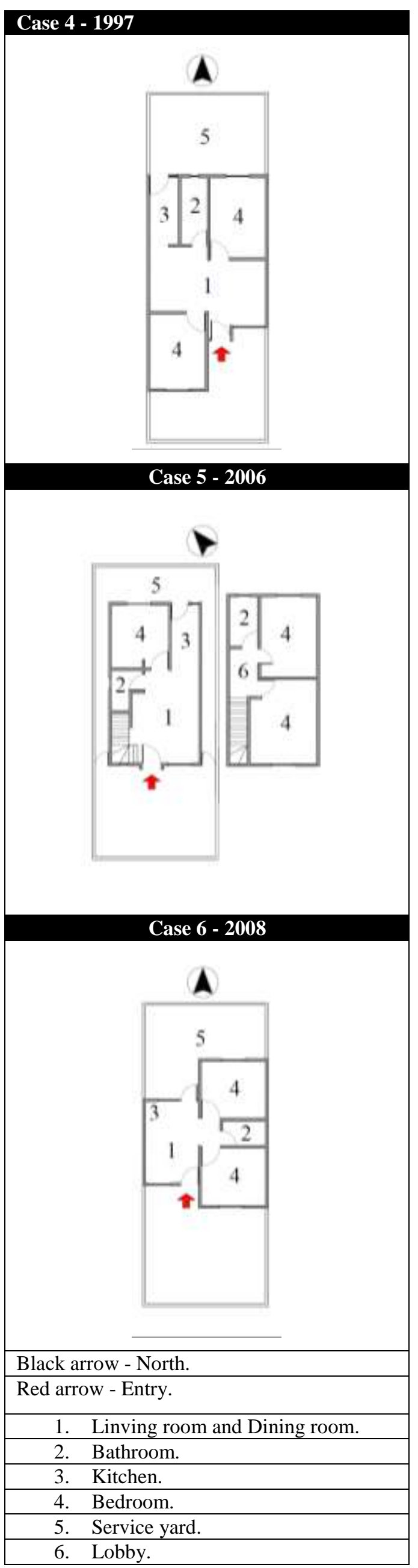

Table 4 House layouts Source: Own Elaboration

ZAPATA-PADILLA, Néstor Juan, GÓMEZ-PEDRAZA, Carlos, BOJÓRQUEZ-VARGAS, Alma Rafaela and HERNÁNDEZGONZÁLEZ, Beatriz Gisela. Comfort's evolution analysis of low-cost housing in Ciudad Valles, S.L.P.Journal of Architecture and Design. 2021 


\section{Methodology to be developed}

This section presents the main objective of the study as well as the process that is conducted to obtain the information and perform the analysis.

\subsection{Objective}

The objective of the present investigation is to register during a period of one year, inside and outside of social interest housing in a series built with block and concrete; environmental variables such as air temperature, relative humidity, wind speed and temperature of the envelope (floor, roof and walls); to analyze with the support of the Olgyay graph, the evolution of the thermal comfort of the home over a period of 20 years in order to identify lapses, zones, locations and orientations with thermal characteristics that provide adequate comfort conditions. The objects of study are six social interest dwellings built in series, which are described in the body of this article as the study cases.

\subsection{Specific objectives}

In addition to conducting a documentary analysis of the literature on the subject, an online survey is applied to verify the general perception of the thermal environment of homes and the city's climate, the municipal archive is consulted to confirm the foundation dates of the Ciudad Valles colonies and obtain a time line to compare the temporal location of the case studies; With the help of pocket meteorological stations and infrared guns, measurements are made inside and outside of each home, to record environmental variables such as air temperature, relative humidity and temperature of the envelope (floor, roof and walls);

Once the data is obtained, an information base is formed in Excel to organize it and obtain comparative graphs to analyze the results. In addition to Excel, the Olgyay diagram is used to represent the environmental comfort that arises in each home by graphing air temperature, relative humidity, and wind.

\subsection{Hypothesis}

The hypothesis from which this research was born, with the support of the surveys, is that for more than 30 years, the thermal comfort within the series social interest housing built with block and concrete in Ciudad Valles, San Luis Potosí it has not evolved to improve the environmental conditions to which the user is subjected, since it does not adhere to the premises of urban design and bioclimatic architecture; which contemplates the adaptability of the properties to the climatic and physical environment of the region to cushion the environmental effects, in such a way that they optimize the perception of the person towards the hygrothermal environment, which is generated by the local climate and especially by the characteristics of formal design, orientation, location and the thermal properties of the housing materials.

\subsection{Problematic}

Disciplines such as architecture and urban planning in themselves must be accommodating and adapt to the physical and climatic context of the region where it takes place, however, current sustainability becomes a plus for these disciplines. The typical house of the warm subhumid region, specifically Ciudad Valles, is characterized by being developed with a classic construction system; based on cement block and concrete; when the materials of the region should be considered first, considering in the first place the energy efficiency of the house, in order to achieve the degree of thermal comfort of the user.

\subsection{Justification}

It is extremely important to develop the architecture and sustainable urbanism of a region, to publicize and analyze the evolutionary behavior of the thermal comfort that is generated due to the environmental fluctuations caused by the materials; like block and concrete; implemented in the construction industry for low-cost housing in a series.

Thus, in order to understand that the technological development of materials and their application are due more to industrial economic development than to the benefit in the environmental quality of the house in favor of the quality of life of the user. 
According to data from INEGI's 2016 national housing inventory, the urban area of Ciudad Valles has more than 12 thousand houses built in series, with an approximate population of 43,000 inhabitants, $15 \%$ of the total population of the urban area. , who currently and for more than 30 years, according to the hypothesis of the present investigation, live in adverse environmental conditions for quality of life and thermal comfort, so the interference of the present study can contribute to the bibliographic update, normative, technical and methodological to integrate materials with physical and physiological characteristics that promote energy efficiency and increase the user's thermal comfort, likewise, the design of housing construction programs with bioclimatic characteristics for the warm subhumid climate, particularly those series houses; and of course also applicable for urban adaptation, remodeling and improvement projects.

\section{Focus}

To carry out the research and better analyze the results, it is considered necessary to proceed with a mixed approach; quantitative descriptive, with which it is possible to expose hard data produced with the support of measurement equipment, in order to understand and describe the causes and consequences of environmental, formal, location, orientation and physiological factors of construction materials involved in the sensation of hydrothermal comfort.

\section{Materials and methods}

To prepare the study, the following actions are carried out:

1. Documentation work and bibliographic analysis, where data of interest are sought such as the formal characteristics of the serial dwelling, the climatological normal of Ciudad Valles and the simple method to verify the hygrothermal comfort of the person. To support the direction of the research, 512 surveys were applied to the perception of the interior environment of the house and the climate of the city. Where 196 responses are received on series homes and 316 responses on self-built homes. This confirms that a warm environment is perceived in old and modern social housing.
2. The temporality of the study cases is defined under three conditions; the first is the period in which INFONAVIT, 1972, and CONAVI, 2006 were founded; the second condition, which is the human capital willing to participate; and finally, the third condition, which is the economic limit available for the investigation, the latter overseeing the principal investigator.

3. With the support of the surveys, the hours in which the data are recorded are limited; 9:00 a.m., 12:00 p.m., 3:00 p.m. and 6:00 p.m. Due to the economic resources and time generated by the registration of the information, the measurements are performed every two weeks.

4. Training on the management of measurement equipment is provided to participants for the project consists of monitoring the environmental conditions of the six homes at the same time for a year, so it is necessary to have personnel for the purpose described.

5. A record sheet is designed to capture the data recorded by the measurement equipment to later capture them to the Excel program for analysis through graphs of the behavior of environmental factors such as temperature, relative humidity, wind and temperature of the envelope.; floor, deck and walls.

6. The Olgyay graph is used to observe if the indoor hygrothermal environment of the house is located inside or outside the comfort zone.

The measurement equipment is obtained for the most part with the main researcher's own resources, and a part with the support of PRODEP 2018, with 14 equipment which is distributed among the six case studies as follows:

A Kestrel model 3500 weather station, which is used to measure the air temperature in degrees centigrade, the percentage of relative humidity\% R.H. and it also records the wind speed in kilometers an hour or meter over second. 
A Steren model HER-427 infrared thermometer with which the enclosure temperature is recorded, floor, deck and walls. Record sheets to facilitate the organization of the data.

\section{Results}

The graphs shown below show the average annual thermal behavior in the exterior and interior of the case studies at 9:00 a.m., 12:00 p.m., 3:00 p.m. and 6:00 p.m. respectively, where it is possible to compare the curves of temperature where it is observed that they behave in a similar way.

The temperature range that is considered comfortable is located between a minimum of $21^{\circ} \mathrm{C}$ and a maximum of $26^{\circ} \mathrm{C}$, limits that are integrated into the temperature graphs to help identify cases where the temperature may be permissible for well-being.

In the external environment of the case studies; at 9:00 am the lowest temperature of the day is recorded, and as the hours pass, the values increase to reach the highest point; maximum temperature; at 3:00 p.m. and then begin to decrease until it reaches 6:00 p.m.

The temperature difference oscillates between $2{ }^{\circ} \mathrm{C}$ at 9:00 am; $1^{\circ} \mathrm{C}$ degree at 12 : $00 \mathrm{~h} ; 2^{\circ} \mathrm{C}$ at 3:00 p.m.; and $1.5^{\circ} \mathrm{C}$ at 6:00 p.m. According to the surveys on the sensation of heat according to the ambient temperature, the oscillation of $2^{\circ} \mathrm{C}$ at any time is not a considerable difference to change the environmental perception, except for the integration of the variability of the percentage of relative humidity. Until now, case three maintains the lowest temperatures so it is important to observe it. Graph 1. Comparison of outside air temperature.

In graph 3 Comparison of indoor air temperature, as in the outdoor environment, the curve of the thermal behavior of the environment remains uniform, where at the beginning of the day; 9:00 a.m., the lowest temperature is recorded and at 3:00 p.m. the highest. It is observed how the curve of case three maintains the lowest values, until it has a difference that approximately reaches $3^{\circ} \mathrm{C}$ in any of the times.
When carrying out a cross observation between the exterior vs. interior temperatures, the average oscillation is up to $2.58^{\circ} \mathrm{C}$ in case 3 , where the exterior environment is hotter than the interior one; while when analyzing the data recorded, it is identified that the variation in temperature inside vs outside reaches $10^{\circ} \mathrm{C}$, with the outside environment being hotter than the inside. Appendix 1.

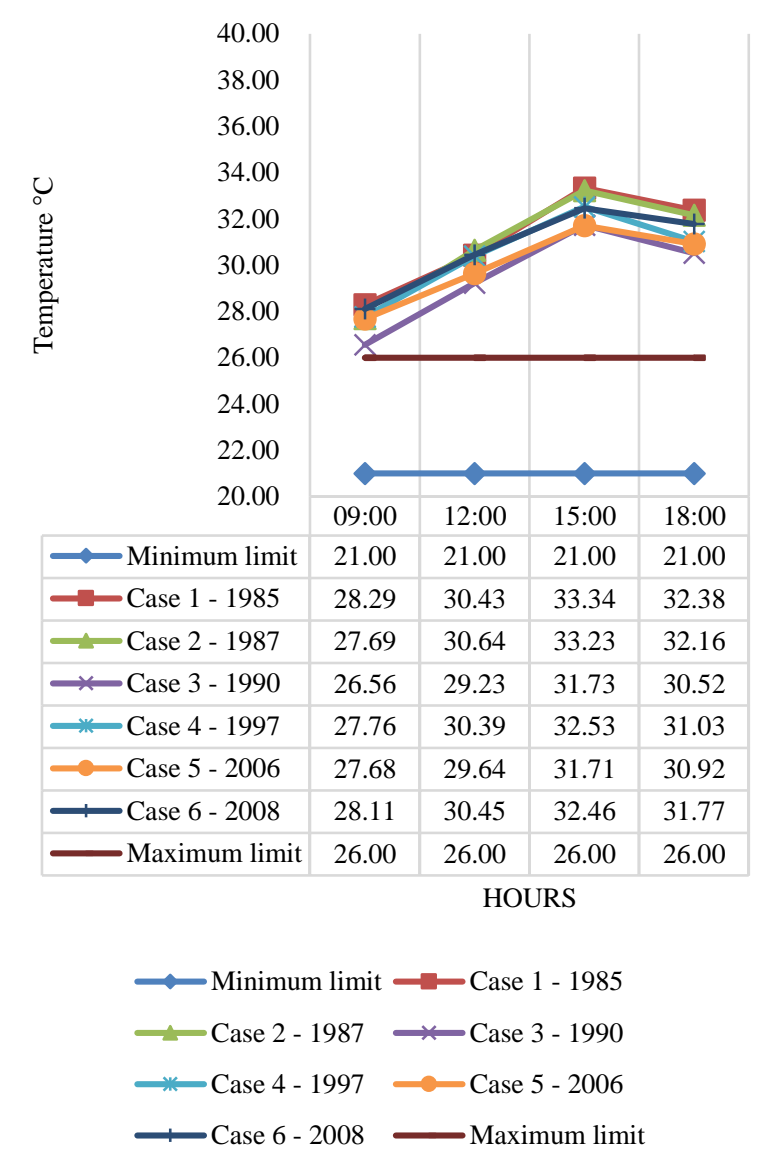

Graph 2 Outdoor air temperatures Source: Own Elaboration 


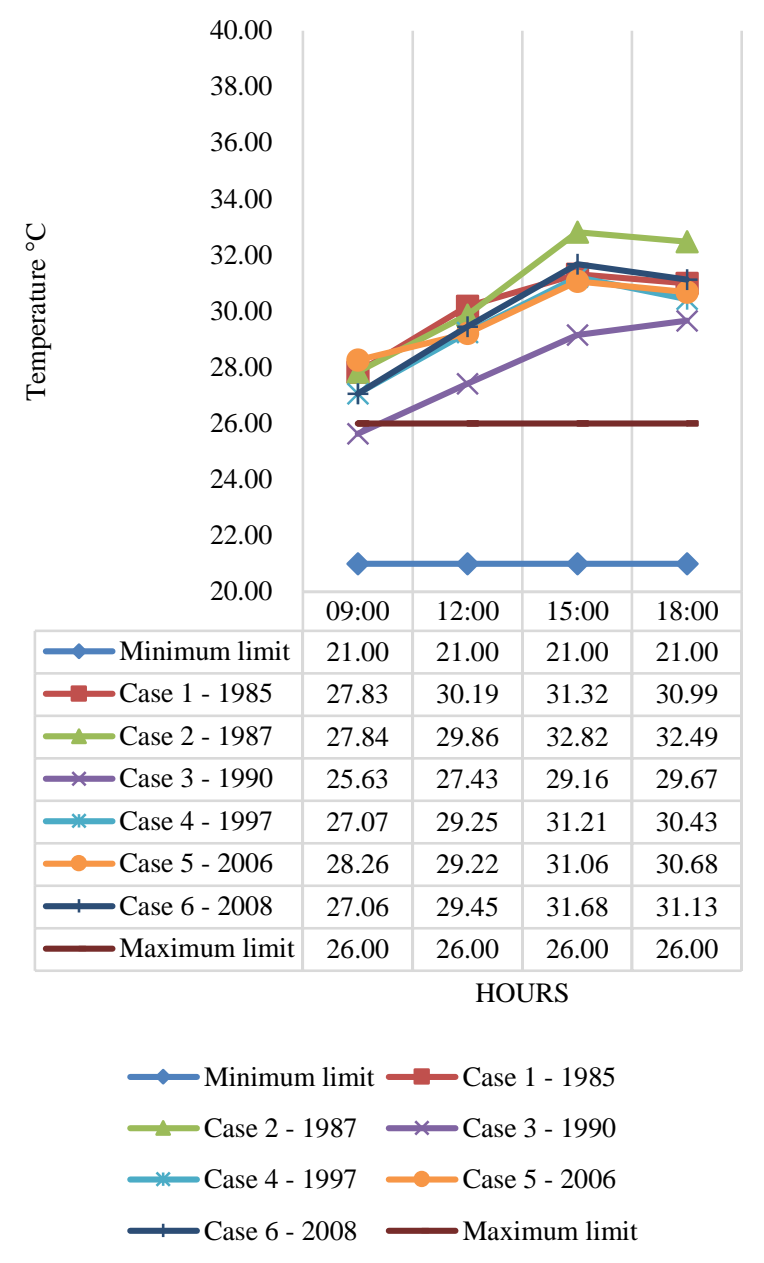

Graph 3 Indoor air temperatures Source: Own Elaboration

The following graphs, Graph 4 and 5, show the behavior of relative humidity, where the principle described in the introduction section is observed; at high temperatures, low humidity; and at low temperatures, the\% R.H. increases. Such is the case at 3:00 p.m. where the temperature reaches its highest peak and the\% R.H. it is at its minimum values. For the six case studies, it is identified that the \% H.R. it is within the permissible limits of at least $20 \%$, and maximums of $55 \%$ and $75 \%$, according to the wedge generated in the Olgyay graph; this implies that the environment maintains a\% R.H. acceptable to infer that the environment could be comfortable if it depended only on this variable.

The presence of wind in all the study cases can be ruled out given that the speed is highly variable and constantly low, barely reaching $0.68 \mathrm{~m} / \mathrm{s}$ as a general average in the indoor environment and with a record of 1.72 $\mathrm{m} / \mathrm{s}$ as maximum., outside the case studies.

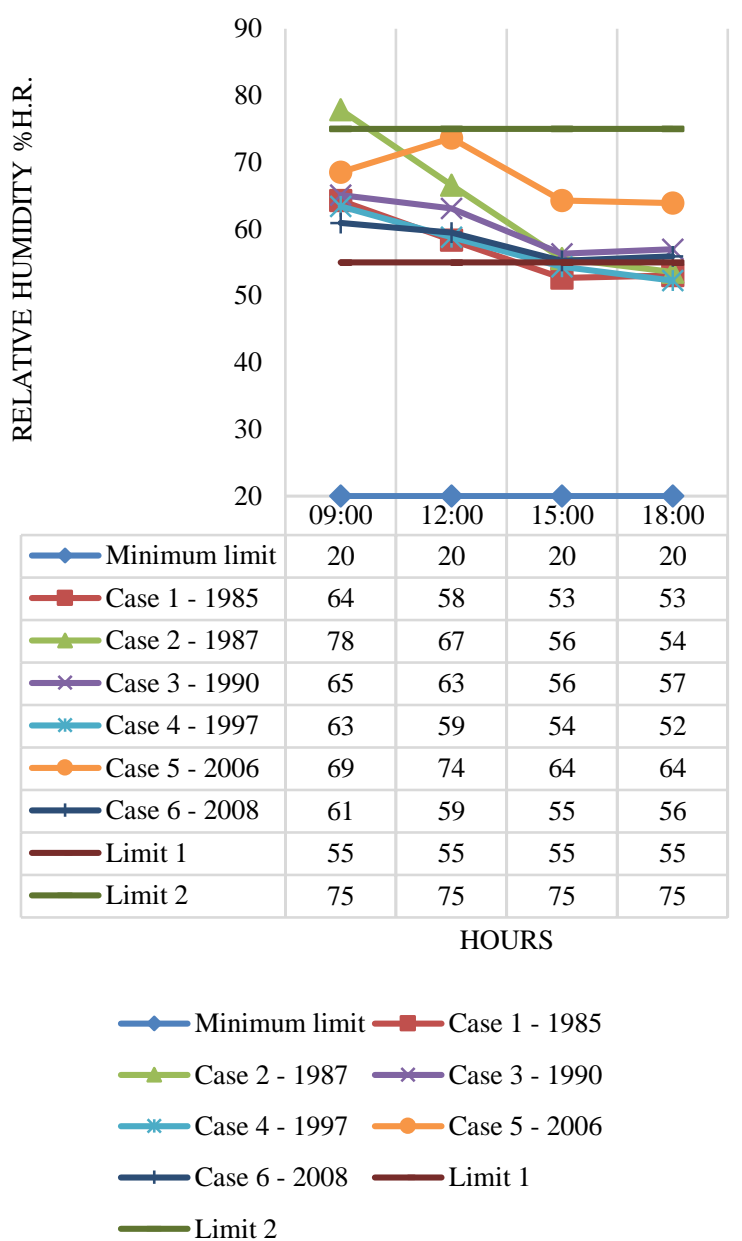

Graph 4 Relative humidity of indoor air Source: Own Elaboration

As a general rule, the $\%$ H.R. it is relatively high in the mornings; as observed in the 9:00 am records; at noon it decreases to reach its lowest register at 3:00 p.m., and then increases its value later at 6:00 p.m.

The average oscillation between the exterior and the interior of the case studies shows that the percentage of differences in the morning is up to $4.57 \%$ at 9:00 a.m. in case two, and at 18:00 the\% R.H. inside and outside is balanced, reducing the difference. 


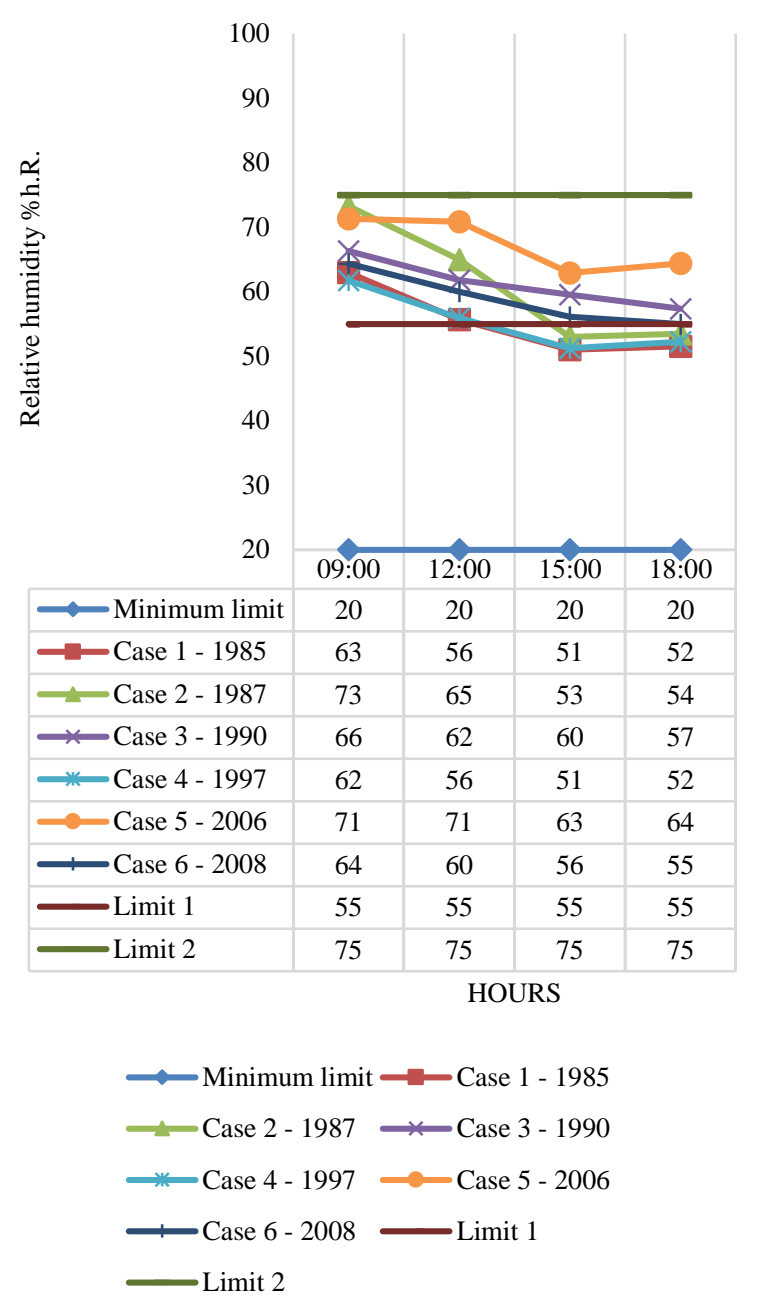

Graph 5 Relative humidity of the outside air Source: Own Elaboration

The most interesting aspect that is observed when performing a cross analysis between the graphs of $\%$ H.R. interior vs exterior; is that the relative humidity inside the case studies remains above the outside value, so it is inferred that; while the temperature of the air and the architectural envelope increases, the thermal sensation of the interior will have negative results on the person; This indicates the need for the wind factor to give movement to the humidity, just as it does outside.

Until now the variables are analyzed independently, and then in the following table 5; the evolution of comfort from the year 1985 to 2008, the cross analysis allows the bioclimatic chart designed by Olgyay to be made is shown, where the temperature, relative humidity and wind speed are plotted in order to verify if the interaction that arises by the combination of climatic variables is appropriate to generate a comfortable environment.

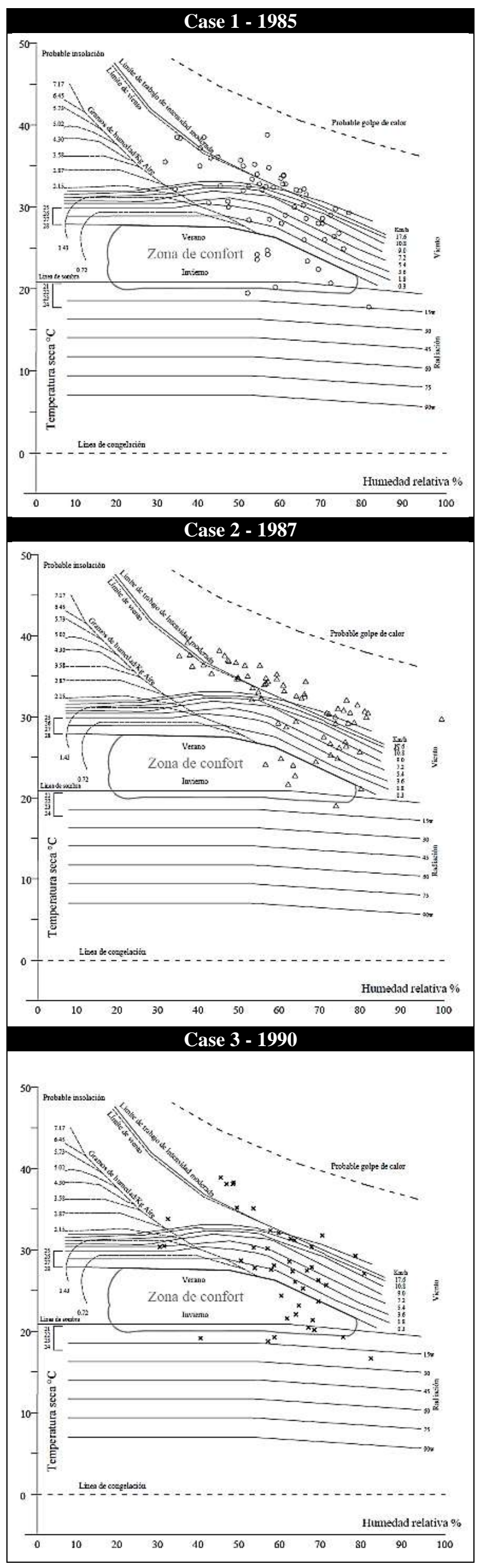

ZAPATA-PADILLA, Néstor Juan, GÓMEZ-PEDRAZA, Carlos, BOJÓRQUEZ-VARGAS, Alma Rafaela and HERNÁNDEZGONZÁLEZ, Beatriz Gisela. Comfort's evolution analysis of low-cost housing in Ciudad Valles, S.L.P.Journal of Architecture and Design. 2021 


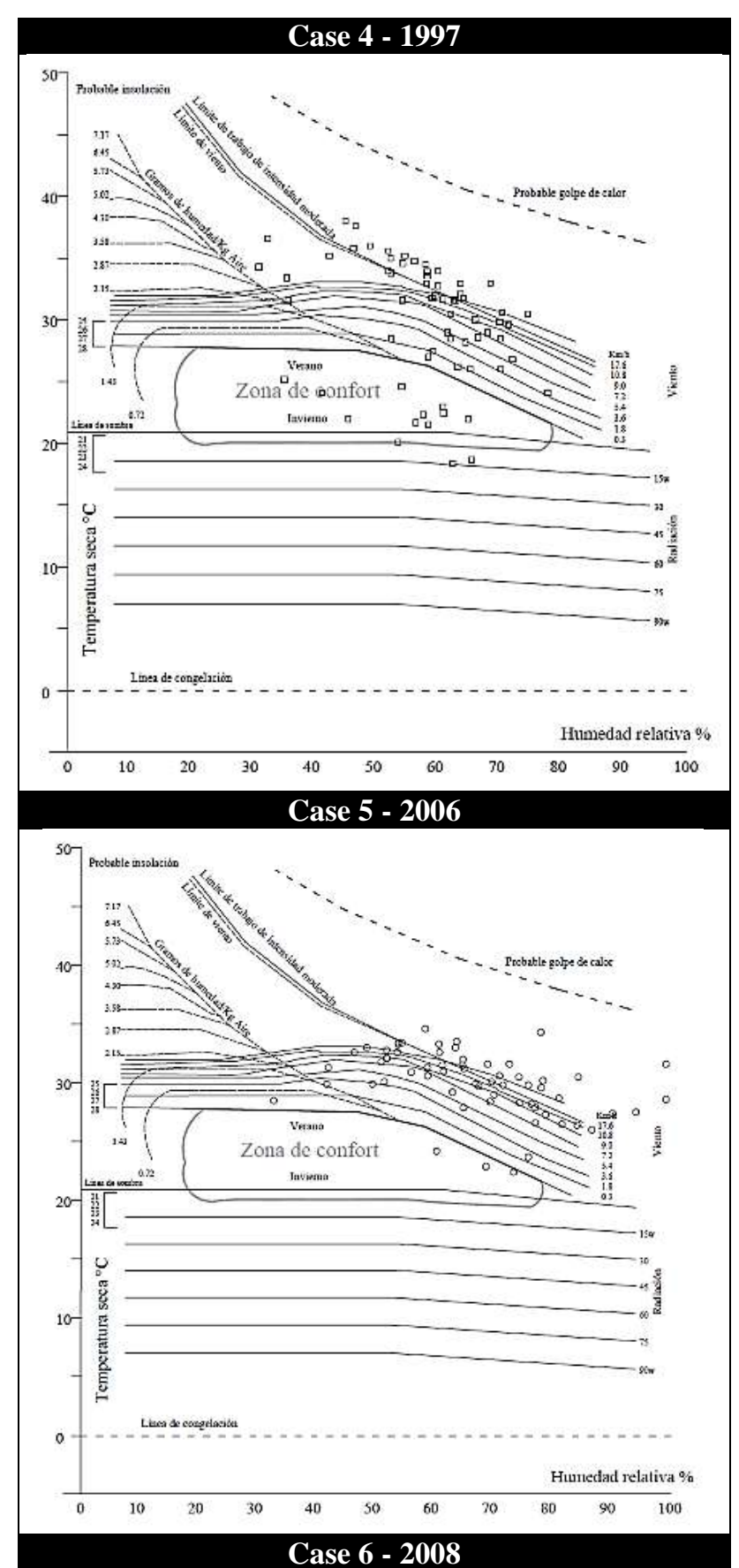

It is observed that from 1987 to 2008, comfort in the home is achieved only in the coldest season of the year, and only at certain times of the day, as is also indicated in table 1 . Evaluation of environmental conditions for Ciudad Valles. Generally, in hot months, the six study cases do not reach thermal comfort for most of the day, except for 9:00 a.m. as in some data that are recorded.

\begin{tabular}{|c|c|c|c|c|c|}
\hline$\ddot{q}$ & 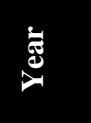 & 晨 & 离 & 童 & 离 \\
\hline C1 & 1985 & 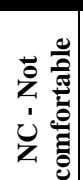 & $\mathrm{NC}$ & $\mathrm{NC}$ & 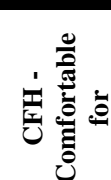 \\
\hline $\mathrm{C} 2$ & 1987 & $\mathrm{NC}$ & $\mathrm{NC}$ & $\mathrm{NC}$ & CFH \\
\hline $\mathrm{C} 3$ & 1990 & $\mathrm{NC}$ & $\mathrm{NC}$ & $\mathrm{NC}$ & CFH \\
\hline $\mathrm{C} 4$ & 1997 & $\mathrm{NC}$ & $\mathrm{NC}$ & $\mathrm{NC}$ & CFH \\
\hline $\mathrm{C} 5$ & 2006 & $\mathrm{NC}$ & $\mathrm{NC}$ & $\mathrm{NC}$ & CFH \\
\hline C6 & 2008 & $\mathrm{NC}$ & $\mathrm{NC}$ & $\mathrm{NC}$ & \\
\hline
\end{tabular}

Table 6 Summary table Source: Own Elaboration

\section{Anex}

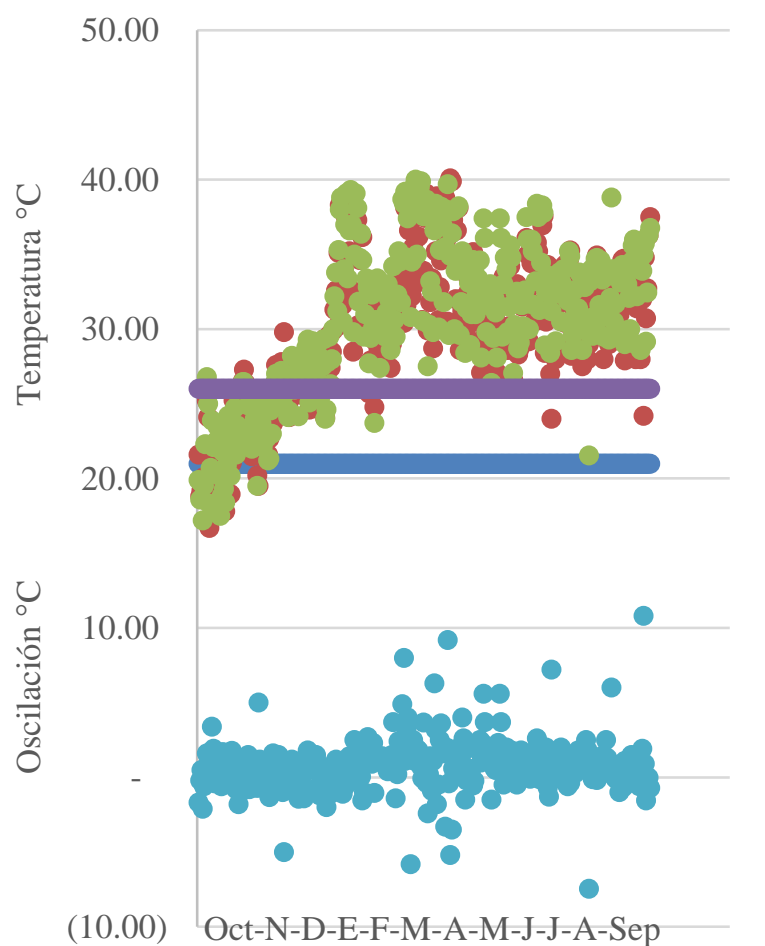

$\begin{array}{ll}\text { - mínima } & \mathrm{C}^{\circ} \text { Interior } \\ \text { - máxima } & \mathrm{C}^{\circ} \text { Exterior } \\ \text { Oscilación }\end{array}$

Graph 6 Maximum Temperature Oscillation ${ }^{\circ} \mathrm{C}$ - Indoor vs Outdoor

Source: Own Elaboration

Table 5 Comfort evolution from 1985 to 2008 Source: Own Elaboration 


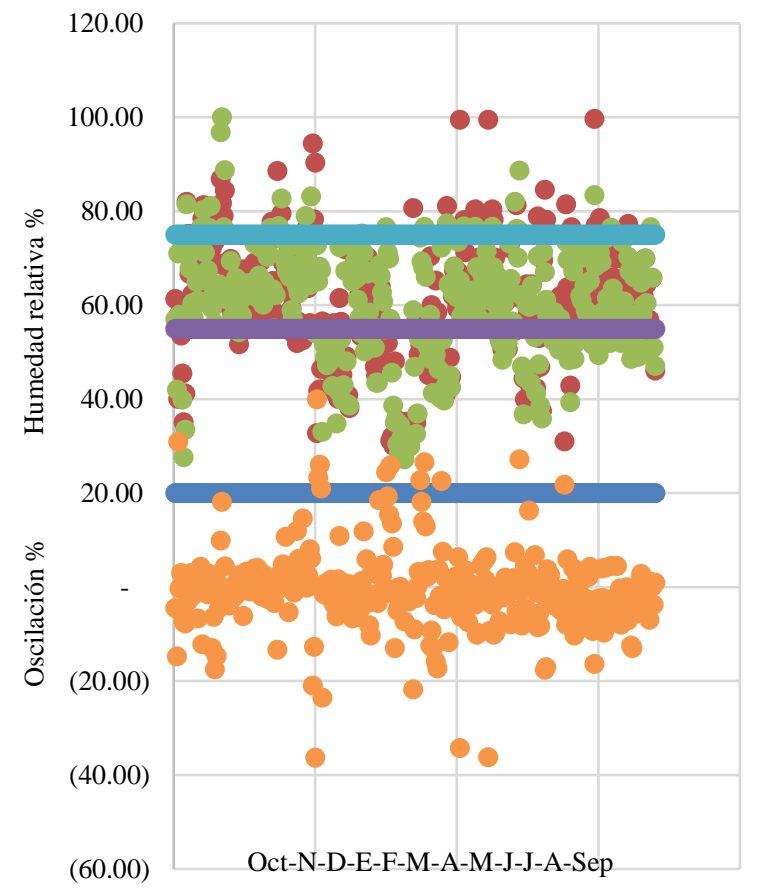

- Minimum $\quad$ H.R. Indoor $\bullet$ H.R. Outdoor

- Limit 1 Maximum Oscillation

Graph 7 Maximum relative humidity oscillation\% Indoor vs Outdoor

Source: Own Elaboration

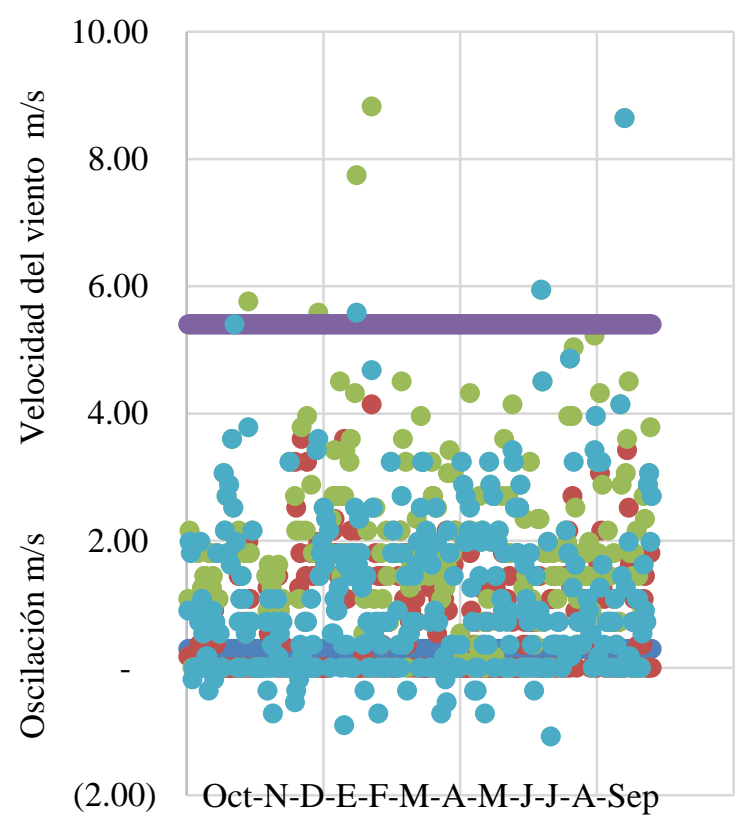

- Mínima $\quad$ Viento Inferior

- Viento Exterior @ Máxima

- Oscilación

Graph 8 Wind speed oscillation in $\mathrm{m} / \mathrm{s}$ inside vs outside Source: Own Elaboration

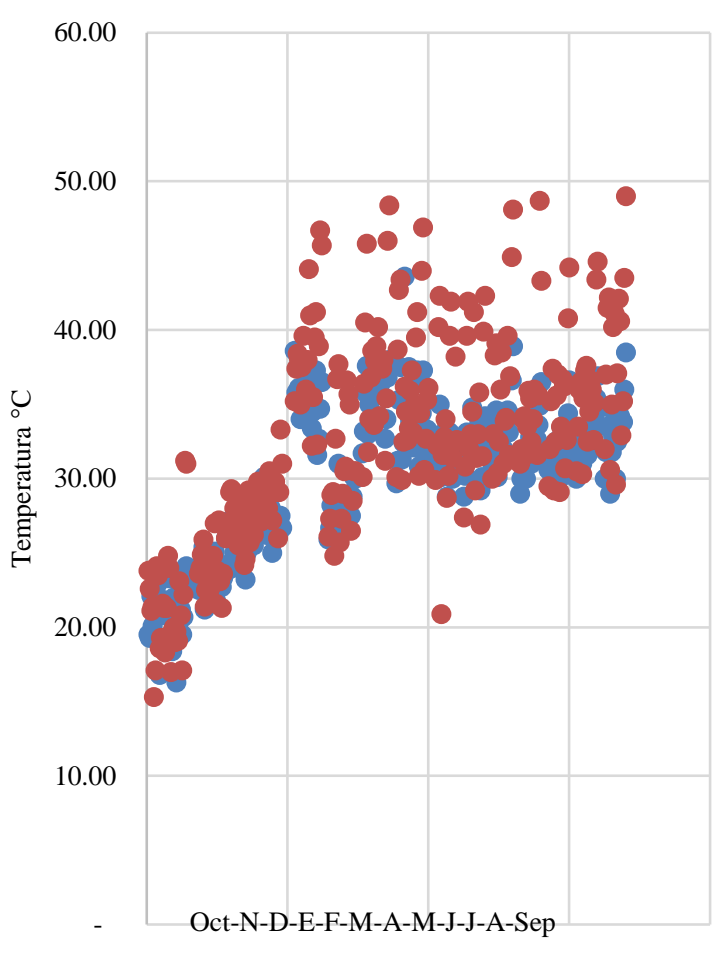

$-{ }^{\circ} \mathrm{C}$ Floor ${ }^{\circ} \mathrm{C}$ Ceiling

Graph 9 Floor temperature record Source: Own Elaboration

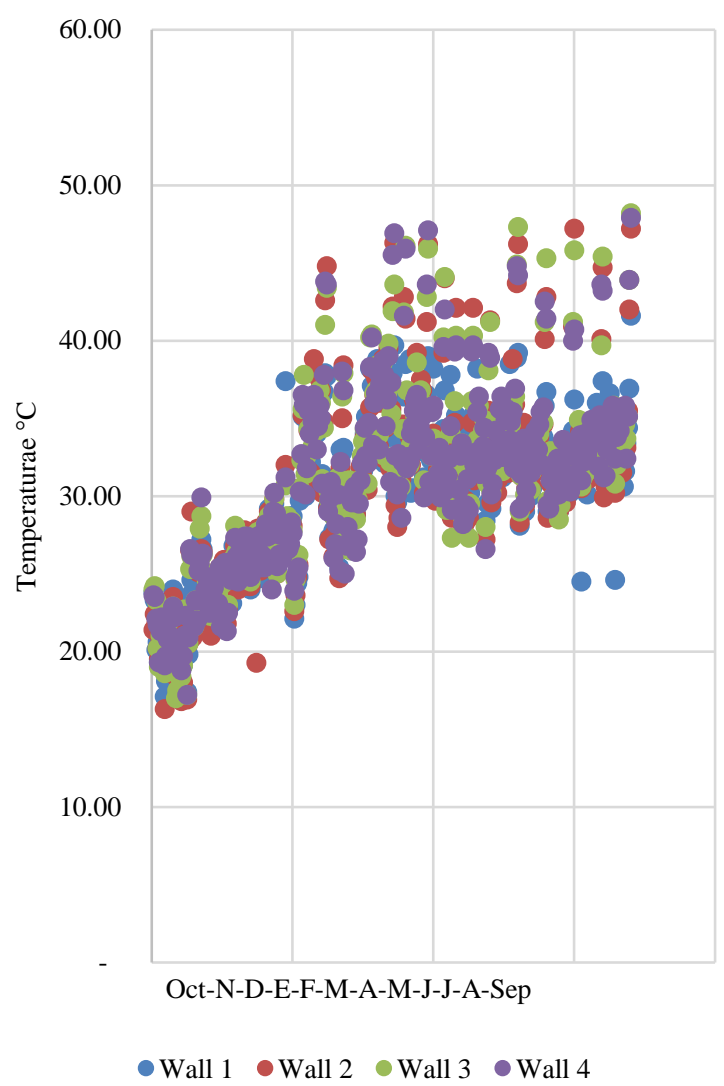

Graph 10 Wall temperature Source: Own Elaboration 


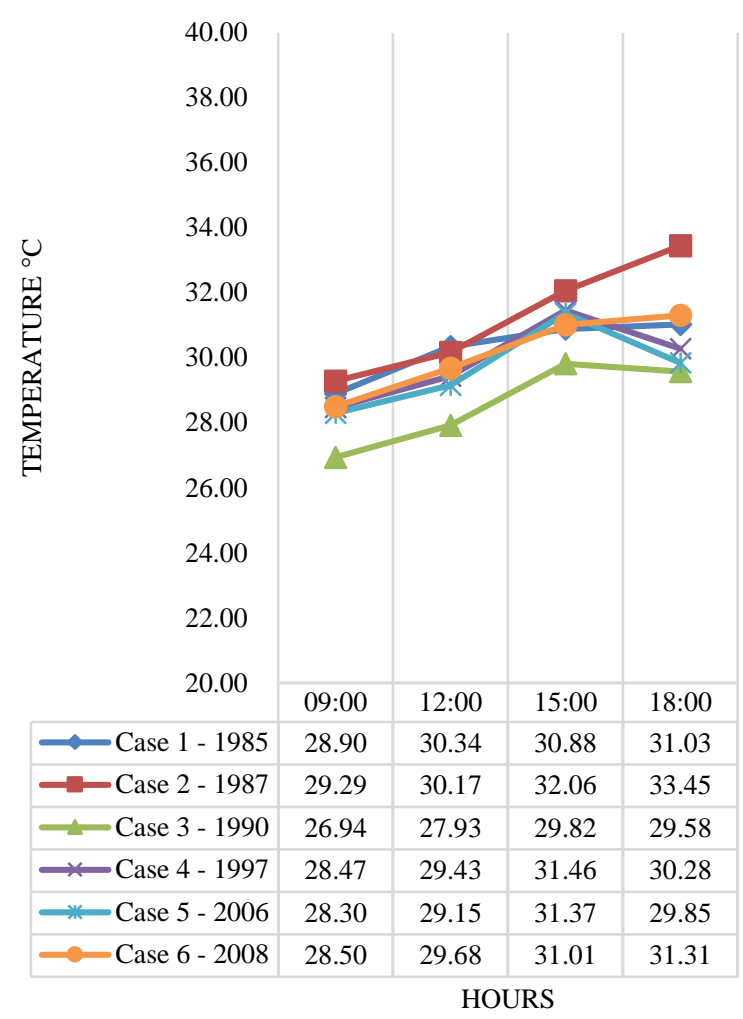

$\longrightarrow$ Case 1 - $1985 \multimap$ Case 2 - $1987 \longrightarrow$ Case 3 - 1990 $\because$ Case 4 - $1997 \multimap$ Case 5 - $2006 \multimap$ Case 6 - 2008

Graph 11 Indoor floor temperature Source: Own Elaboration

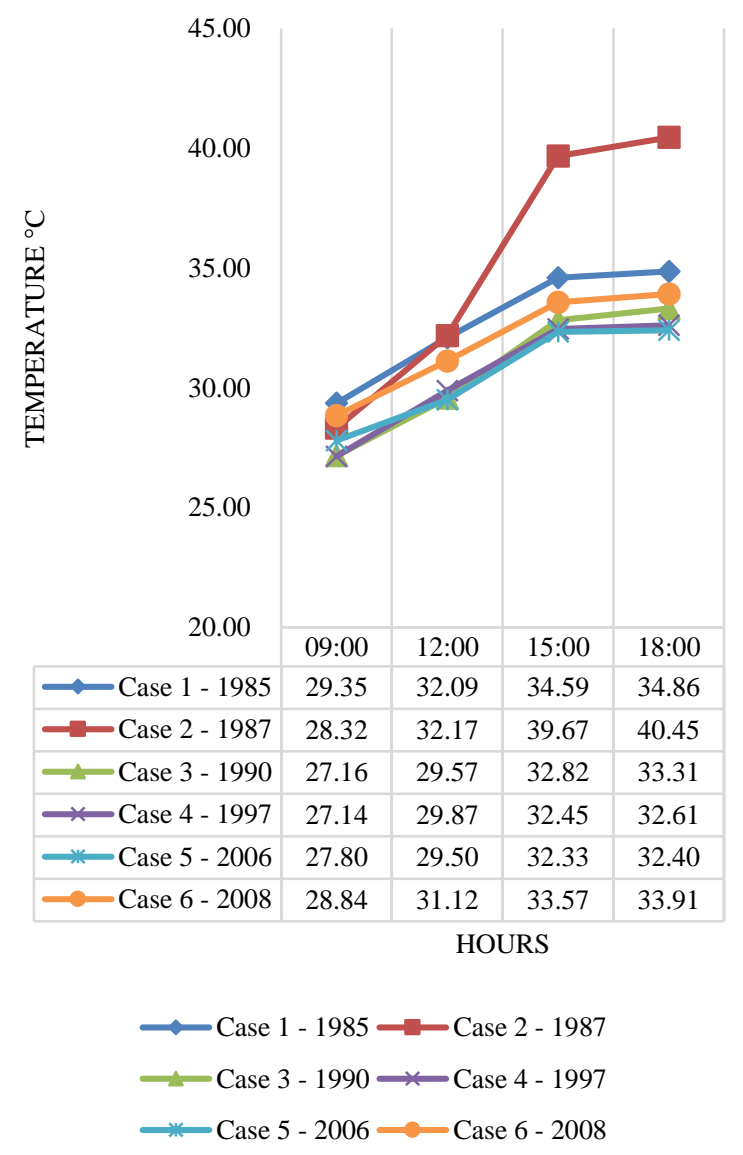

Graph 12 Ceiling temperatura. Indoor Source: Own Elaboration

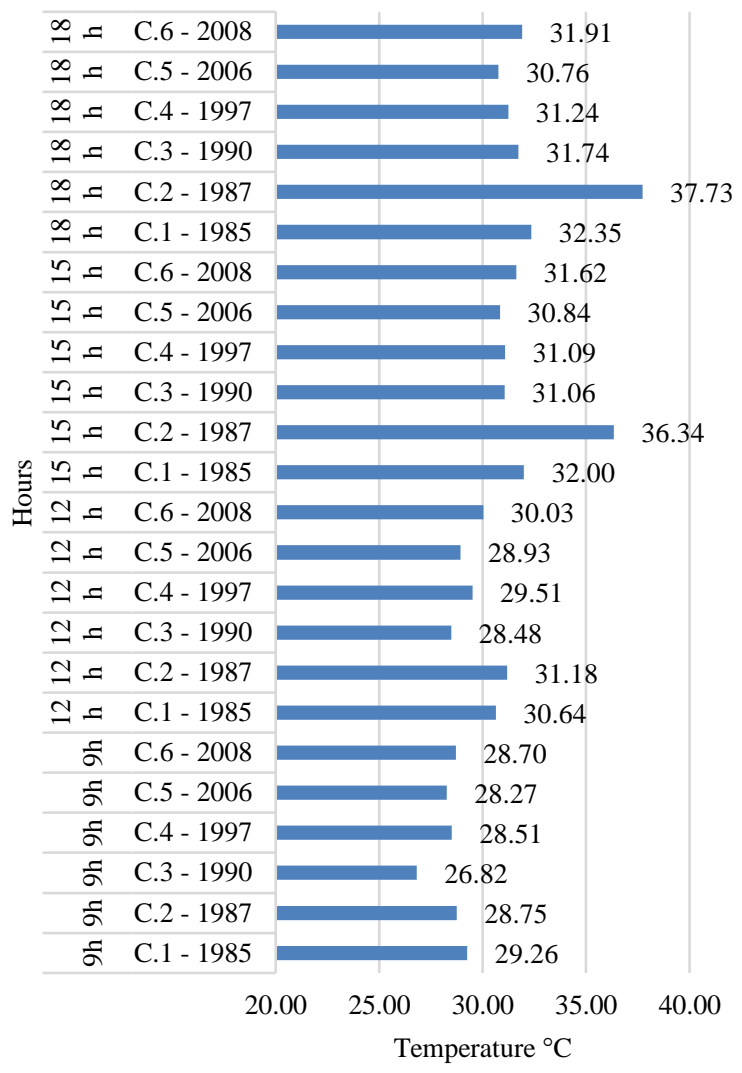

Graph 13 Interior temperature of the walls Source: Own Elaboration

\section{Acknowledgments}

The progress of this research is only possible thanks to the group of people who formed an excellent work team and who without any obligation, gave their support, trust and attention to the team of researchers, and who surely sacrificed moments of their life and family to be able to contribute their time, enthusiasm and dedication to monitor the case studies for a whole year, every two weeks, regularly on Saturday, and surely not only at 9:00 a.m., 12:00 p.m., 3:00 p.m., 6:00 p.m. as described in this document. Thank you very much: Nayla and company, Jerónimo and wife, Rebeca, Óscar and Yosseline.

\section{Conclusions}

According to the crossover analysis between air temperature, relative humidity and wind, it is observed in Olgyay's graph that the environment inside and outside of the case studies is uncomfortable in hot months. Older homes, as well as modern homes, do not provide adequate environmental conditions for the person, even housework that is carried out in hot seasons can cause heat stroke. 
To improve the climatic conditions, it is necessary to increase the wind speed and specially to decrease the ambient temperature and the radiant temperature of the architectural envelope. This is achieved by substituting construction materials for those with better thermal characteristics, in this case changing the cement block or its finish, for other material such as the adobe block that, according to the bibliography being studied, conserves for less, time heat; It is also possible to improve the formal design of the houses such as the expansion and change of the location of openings to encourage the entry of gusts of wind, modify the height of the roof to increase the volume of air that is in direct contact with it and that transmits the heat from the radiant temperature of the slab.

It is important to state that it is disconsolate to show that construction materials for more than 30 years ago are still being used, even when it is shown in other studies besides this one, that the thermal characteristics are inappropriate for certain climatic zones such as the warm subhumid zone, among others, and that the technological evolution for the creation and implementation of new construction systems based on suitable materials has a selective nature aimed at industrial economic benefit, rather than improving the environmental habitability conditions in homes.

According to the averages of the climatic parameters, case 3 is the one with the best relationship between temperature and relative humidity, and since it is located on the outskirts of the city, it follows that the proximity with abundant vegetation favors a better outdoor microclimate of the zone and therefore, the values of the interior environmental parameters are below, the rest, without reaching the comfort zone.

This shows that green areas produce better urban climatic conditions, so that the decrease in the density of buildings with the application of vertical construction can be an alternative option to generate areas with better bioclimatic conditions.
And as a last point from the researchers, it is essential to continue with the analysis and design of materials with better thermal properties according to the local climate in order to integrate them into the standards, construction manuals and, in due course, to the legislation on projects applicable to the area of serial and social interest housing construction both for the private initiative and the public sector.

\section{References}

Álvarez, A. López, (2004). Cambio climático y microclimas urbanos en ciudades del centro de cuba. Reflexiones para el planeamiento a través de sig.. Argentina. Vol. 8, $\mathrm{N}^{\circ}$ 1, 2004. Impreso en la Argentina. ISSN 0329-5184

American Society of Heating Refrigerating and Air Conditioned Engineers [ASHRAE]. (2017). ASHRAE STANDARD 55-2017 Thermal environmental conditions for human occupancy. Atlanta.

Barona Díaz, Edgar, \& Sánchez Rodríguez, Fernando (2005). Características de la vivienda de interés básica, socialy económica urbana en Puebla-México. e-Gnosis, (3),0.[fecha de Consulta 19 de Octubre de 2021]. ISSN: Disponible en: https://www.redalyc.org/articulo.oa?id=730003 13

Chicas Molina, Juan Carlos (2012). Morfología urbana y Clima urbano, estudio de microclimas urbanos en Santiago de Chile, mediante la aplicación del concepto de cañón urbano e índices de confort térmico. Instituto de Estudios Urbanos y Territoriales de la Pontificia Universidad. Santiago de Chile.

Geiger, R., Aron, R. H., Todhunter, P. (1995). The Climate Near The Ground, $5^{\mathrm{a}}$ edición. Vieweg \& Sohn. Weisbaden.

Givoni, Baruch (1998). Climate considerations in building and urban design. John Wiley \& Sons, Inc. United States of America.

Giraldo Castañeda, W., Czajkowski , J. D., \& Gómez , A. F. (2021). Confort térmico en vivienda social multifamiliar de clima cálido en Colombia. Revista de Arquitectura (Bogotá), 23(1), 115-124. https://doi.org/10.14718/RevArq.2021.2938 
H. Ayuntamiento de San Luis Potosí (2018). El plan del centro de población estratégico San Luis Potosí Soledad de Graciano Sánchez. México.

Higueras, Ester (2013). Urbanismo Bioclimático. (1a edición, 5a tirada) ISBN: 9788425220715 .

Higueras, Ester y TUMINI, Irina (2013). "El Microclima en los Espacios Abiertos. Estudio de casos en Madrid." Universidad Politécnica de Madrid. ww.eesap.org/Biblioteca/EESAP2_itumini.pdf

Instituto nacional de estadística y geografía INEGI (2016). Anuario estadístico y geográfico por entidad federativa 2016. Instituto Nacional de Estadística y Geografía. México. ISBN 978607-739-993-3.

Instituto nacional de estadística y geografía INEGI (2017). Anuario estadístico y geográfico de San Luis Potosí 2017. México.

Lynch, Kevin (2008). La imagen de la ciudad. Gustavo gili. SL, Barcelona, 1984, 1998.

Monroy, Manuel Martín (2001). Claves del Urbanismo Bioclimático. Artículo publicado en revista BASA. ULPGC Basa, ISSN 0213-0653, №. 24, 2001, págs. 148-159.

Ochoa, José Manuel y MARINCIC, Irene (2002). Diseño Microclimático de Espacios Exteriores confortables y energéticamente eficientes. XXVI Semana Nacional de Energía Solar, Noviembre de 2002, Chetumal, México. Oke, T.R. (1987). Boundary layer climates (2nd ed.). London: Routledge.

Olgyay, V. (1998.). Arquitectura y Clima: Manual de Diseño Bioclimático para Arquitectos y Urbanistas. Gustavo Gili.

Roux Gutiérrez, Rubén Salvador, \& Garcia Izaguirre, Víctor Manuel (2014). CONFORT TÉRMICO VERSUS CONSUMO ENERGÉTICO EN VIVIENDAS DE INTERÉS SOCIAL EN CLIMA CÁLIDO HÚMEDO. Revista Legado de Arquitectura y Diseño, (16),123-140.[fecha de Consulta 10 de Noviembre de 2021]. ISSN: 2007-3615. Disponible en: https://www.redalyc.org/articulo.oa?id=477947 304009
Schiller, Silvia (2001). Isla de calor, Microclima Urbano y Variables de Diseño, estudios en Buenos Aires y Rio Gallegos. Argentina. ISSN 0329-5184

Trujillo, Carlos y OSPINA, Ricaurte y PARRA, Hernando (2010). Arquitectura y Urbanismo Bioclimático: Presente y Futuro para el Hábitat del Hombre Contemporáneo. Scientia et Technica Año XVII, No 46, diciembre 2010. Universidad Tecnológica de Pereira. ISSN 0122-1701 revistas.utp.edu.co

Zapata, Néstor (2017). Confort humano en microclimas urbanos (Calle Miguel Hidalgo, Cd. Valles, SLP, MX.). TLATEMOANI Revista Académica de Investigación. No. 25, agosto 2017. Eumed.net. España. ISSN: 19899300 revista.tlatemoani@uaslp.mx 